\title{
The Mediating Role of Organizational Identification in the Relationship between Quality of Work Life and Organizational Agility: A Study on Menoufia University Hospitals
}

\author{
Wageeh A. Nafei ${ }^{1}$ \\ ${ }^{1}$ University of Sadat City, Menoufia, Egypt \\ Correspondence: Wageeh A. Nafei, University of Sadat City, Menoufia, Egypt.
}

Received: November 30, 2017 Accepted: December 13,2017 Online Published: December 19,2017

doi:10.5539/ibr.v11n1p184 URL: https://doi.org/10.5539/ibr.v11n1p184

\begin{abstract}
The overall objective of the study is to identify the role of Organizational Identification (OI) as a mediating variable in interpreting the impact of Quality of Work Life (QWL) on Organizational Agility (OA). The research community is composed of all employees at Menoufia University hospitals (University Hospitals, National Liver Institute and Students Hospitals) in Egypt. Due to the time and cost constraints, the researcher adopted the sampling method to collect the necessary data for the study. The appropriate statistical methods were used to analyze the data and test the hypotheses.

The research discovered a number of results, the most important of which is the existence of (1) that there is a positive effect between QWL and OI, (2) the existence of a positive impact between the dimensions of QWL and OA, (3) there is a positive effect between the dimensions of OI OA, (4) there is a positive effect of OI as a mediating variable in explaining the effect of QWL on OA at Menoufia University hospitals; that is, OI plays the mediating role in the relationship between QWL and OA. There is an impact on QWL on OA through OI at Menoufia University Hospitals.

The study referred to a number of recommendations, the most important of which are: (1) re-studying and structuring of the system of wages in the hospital in a way that allows them to get the appropriate returns for their efforts, (2) providing a safe and healthy working environment at the University hospital, (3) improving QWL in terms of providing promotional opportunities, objectively, in accordance with specific standards and controls, (4) activating the training programs so that they are not limited to specific categories, (5) involving the employees in the decision making process, in view of the nature and sensitivity of the hospital work, which relates to the lives of citizens and requires a large amount of freedom to make decisions.
\end{abstract}

Keywords: quality of work life, organizational identification, organizational agility

\section{Introduction}

Quality of Work Life (QWL) is not a new issue with the organization, and most studies have confirmed after that quality of life is the most important theme that the organization must take into account (Narehan et al., 2014).

The issue of quality of life was first introduced in 1972 at the International Labor Relations Conference, and this theme was given more attention when General Motor launched several quality programs to improve and reform work (Gayathiri \& Ramakrishnan, 2013). QWL plays an important role for employees in all organizations of all types and sizes. Life in the workplace is as important as personal life, and the element of satisfaction is very important in both of them (Sharma \& Verma, 2013). It becomes a key determinant of the success and stability of organizations of all types and sizes (Koonmee et al., 2010). It is an important part of improving and enhancing the performance of organizations of all types and sizes. The quality of life of health care organizations creates positive results for health providers and recipients (Burtson \& Stichler, 2010).

Organizational Identification (OI) is a relatively recent concept that has emerged in administrative research in general (Liu, et al., 2011). The researchers' efforts in the literature of organizational behavior have shown that OI achieves individual self-esteem and increases the level of belonging among the individual and the organization (Saks, 2006). 
OI is one of the forms of social identification. All organizations seek to have a clear link and integration between their vision and mission and their employees in a manner that contributes to the achievement of their goals efficiently and effectively (Simon, 2000).

Because the human mind is unable to observe changes in the environment, and the current business environment is becoming increasingly complex and changing (Zain et al., 2005), the organization is in dire need of human capital characterized by Organizational Agility (OA), whose dimensions are sensing agility, decision-making agility and acting agility (Markos \& Sridevi, 2010; Warr \& Inceoglu, 2012).

\section{Quality of Work Life}

\subsection{Quality of Work Life Concept}

QWL can be defined from two perspectives: the first from the personal point of view; namely, the perception of employees from the same place of work, and the second from the objective point of view, a set of programs and activities related to the work of the organization such as salaries, health care, decision, and occupational safety (Nekouei et al., 2014). It is the right working environment that promotes and develops employee satisfaction through rewards, job security, as well as opportunities for advancement (Gayathiri \& Ramakrishnan, 2013). QWL is the degree of excellence and conditions of work that determine the nature of the relationship between the worker and the environment in which he works, in addition to the human dimension, which contributes to the overall achievement of job satisfaction of employees; thus, improving the ability of individuals to perform work, and thus the performance of the organization as a whole (Shani, 2013). It is a program that combines a set of principles that seek to satisfy the employees of the organization, as well as increasing their desire to learn, and to cope with changes that occur in environment conditions (Mirkamali \& Thane, 2011).

QWL is a set of programs, methods and theories that provide an appropriate work environment in a way that helps employees perform the tasks assigned to them, in addition to the need to give employees the authority and responsibility that suits their business (Gupta \& Sharma, 2011). It is a philosophy based on the fact that the employees of the organization are the most important resources, and therefore must be treated with respect and appreciation (Reddy \& Redd, 2010). QWL is an entry that contains a range of issues such as rewards, and the nature of the time spent by the worker in the work environment (Pizam, 2010).

\subsection{Quality of Work Life Dimensions}

There are eight dimensions of QWL (Timossi et al., 2008; Parvar et al., 2013). They are as follows:

\subsubsection{Wage Justice}

The remuneration that the individual receives from the organization must be commensurate with its needs on the one hand, and its effort on the other hand. There must be fixed ways to determine the level of remuneration that an individual receives, since many employees feel that what they receive is not commensurate with the effort they are doing.

\subsubsection{Working Conditions of the Organization}

The organization must provide safe and healthy working conditions for all its personnel so as not to be exposed to working conditions that may affect their mental or physical health. Trade unions played an important role in this area through government legislation, which in turn improved the working conditions of the Organization.

\subsubsection{Promotion Opportunities}

Promotion opportunities play an important role in the lives of people working in the organization, and there must be real opportunities for growth and promotion on an ongoing basis, which improves the quality of the organization's career.

\subsubsection{Commitment to the Principles of the Organization}

Individuals working in the organization must adhere to the principles and rules for their work. On the other hand, there must be an obligation on the part of the organization to take into account the fairness in the distribution of the rewards for the employees.

\subsubsection{Training and Development Opportunities}

The training and development of employees play an important role in improving and increasing the knowledge related to work, which is positively reflected in increasing the degree of job satisfaction and thus improve the quality of the career in addition to increasing the growth of knowledge of the staff helping them solve the problems at work. 


\subsubsection{Social Integration}

The characteristics of the work environment in the organization have a great impact on the individuals working on the one hand, as well as their respect for these characteristics, on the other hand, the most important of which is the sense of belonging to the organization, the existence of real opportunities for promotion, and the nondiscrimination among the individuals working in the organization.

\subsubsection{Work Life and Total Life}

There is a relationship between private life and working life in the organization. Given the surrounding environmental conditions, where competition is increasing, it is difficult to separate private life from the work life of the organization. It should be noted that most employees have a strong desire to balance their personal and recreational lives and their practical lives.

\subsubsection{Social Responsibility}

The goal of the organization is not only to make a profit, but also to take responsibility for society. Managers in all organizations must take into account the social responsibility of the organization, which requires the creation of an appropriate strategic plan that will help the organization survive. An organization that operates in a socially irresponsible manner has a short life and; therefore, does not have the status of success and stability.

\section{Organizational Identification}

\subsection{Organizational Identification Concept}

OI is the existence of some kind of correlation between the worker and the organization in which he or she operates. This can be illustrated by the need to align the objectives of the organization with those of its employees and the need for the individual to promote and develop the organization in which he or she works, whether at work or outside (Karanika-Murra, 2015).

OI is the degree to which an individual knows for himself in the organization the same characteristics and attributes that the organization is thought to be described (Milton \& Westphal, 2005). OI is the individual's adoption of the values and objectives of the organization as its own values and goals. In other words, OI is the process of integrating the desires of personal employees with the wishes of the organization in which they work (Johnson et al., 1999).

OI is a type of interdependence and positive psychological compatibility between the individual and the organization in which he operates (Stuart, 1999). It is the unification of the values and goals of the individual with the organization at which he works, his sense of integration, loyalty and commitment to it, and the desire to belong and membership (Street, 1994). OI is the degree to which characteristics of an individual are similar to those of the organization in which they operate (Dutton, et al., 1994). It is the unity and conformity of the individual with the organization in which he operates, and his sense of allegiance and belonging to it (Mael \& Ashforth, 1992).

OI is that individuals' working in the organization reshaping their concepts to conform to the concepts of the organization at which they work (Tompkins \& Cheney, 1985). It is the process of integrating and matching the goals and characteristics of the individual to the goals and characteristics of the organization in which he operates (Hall et al., 1970). It is an individual's perception and conformity with the organization to which he belongs. OI includes three dimensions: loyalty, similarity, and membership (Cheney, 1982).

\subsection{Organizational Identification Dimensions}

The dimensions of OI are organizational loyalty, organizational similarity, and membership (Cheney, 1982). These can be illustrated as follows:

\subsubsection{Organizational Loyalty}

Organizational loyalty is the loyalty of the individual to the organization at which he works and the enthusiasm towards achieving its goals and defending it in front of others.

\subsubsection{Organizational Similarity}

Organizational similarity is the individual's perception of the existence of a set of characteristics, values, and goals shared with the members of the organization in which he operates.

\subsubsection{Membership}

Membership is the concept of the individual itself in terms of the extent of its association with the organization, and the sense of belonging and the psychological connection between him and the organization and its members. 


\section{Organizational Agility}

\subsection{Organizational Agility Concept}

Organizational Agility (OA) is an integrated system based on the efficient and effective use of physical and intangible technology as well as the human resources available to the organization to meet the rapidly changing market needs (Park, 2011). It is the organization's ability to meet the needs and wishes of its customers quickly and with appropriate quality (McCarthy et al., 2010).

$\mathrm{OA}$ is a set of ideas that seek continuous improvement in the organization and efficient use of physical and intangible resources efficiently and effectively (David, 2009).

OA is the process of focusing the organization's activities by focusing on particular markets and products in order to achieve excellence in the organization's offerings (Hill \& Jones, 2009). OA is a set of capacities that seek to achieve agility in the organization (Sherehiy, 2009).

OA is the organization's ability to excel quickly and flexibly in response to changing market needs, as well as responding effectively to these changes both in the local and global environment (Sherehiy, 2008). It is an administrative strategy aimed at maintaining the organization's resources and achieving the customers' wishes in a timely manner (Hitt et al., 2007). OA is the ability of the organization to respond quickly to opportunities and to counter threats at the right time (Overby et al., 2006).

$\mathrm{OA}$ is the ability of the organization to carry out a set of well-defined and effective tasks (Ardchvile et al., 2003). It is the ability of the organization to respond to market trends and to deliver its products or services faster than competing organizations (Kapltrick, 2003).

$\mathrm{OA}$ is the organization's ability to function distinctly in a changing environment, delivering products efficiently and effectively. $\mathrm{OA}$ is the ability to survive under changing environment conditions, through rapid response to the needs and desires of consumers. OA is the organization's competitiveness through the use of best practices that meet the changing needs and desires of consumers. In other words, OA is the ability of the organization to respond quickly to unexpected opportunities, as well as to develop solutions to meet expected needs (Tsourveloudis \& Valavanis, 2002).

OA consists of three basic elements: sensing agility, decision-making, agility and acting agility (Pavlou \& Elsawy, 2010; Sambamurthy et al., 2003).

OA should be noted that despite the diversity of concepts of OA, they agree in their content that they have speed and flexibility in meeting the changing needs and desires of markets, the production of high quality products, the ability to respond to and deal with global environmental variables, the ability to use new technology, and the integration and harmonization between business units among themselves and with other organizations (Sherehiy, 2008).

\subsection{Organizational Agility Dimensions}

The dimensions of OA are sensing agility, decision-making, agility and acting agility (Warr \& Inceoglu, 2012; Markos \& Sridevi, 2010; Park, 2011; Thomay et al., 1993). They are as follows:

\subsubsection{Sensing Agility}

Sensing agility is the ability of the organization to examine and view events and changes in the environment whether related to customers, new competitors, or technology used by other organizations. The Organization must have the capacity to cope with these changes in a timely manner. Sensing agility is the ability of the organization to strategically monitor environmental conditions that have an impact on the organization's strategy and performance. The primary task of the sensor is to collect and analyze information on environmental changes and events well and effectively. This task is linked to the decision-making process and the need to adapt the organization to environmental changes.

\subsubsection{Decision Making Agility}

Decision-making is the ability to collect, record, analyze and evaluate information from multiple and diverse sources to identify and exploit opportunities, as well as to reduce the impact of threats in the environment on the organization and to develop strategic plans that help them effectively.

The decision-making task consists of several interrelated activities, the most important of which is the collection, recording and analysis of information from different sources in order to identify the implications of the activities and functions of the organization. The decision-making task seeks to maximize opportunities and minimize the impact of threats on the organization. 


\subsection{Acting Agility}

Acting agility is the ability of an organization to utilize its available resources efficiently and effectively, and to restructure its operations and relationships in such a way as to help the organization deliver its products in a timely manner. Acting agility consists of a range of activities whose primary objective is to regroup the Organization's resources and to adjust its operations to cope with changes in the surrounding environment. Acting agility invol ves identifying competing organizations in the market by working on new products, as a good organization must recognize its competitors in order to survive and survive in the changing environment.

\section{Research Model}

The proposed comprehensive conceptual model is presented in Figure (1). The diagram below shows that there is one independent variable of QWL There is one dependent variable of OA. There is one mediating variable of OI. It shows the rational link among the three types of observed variables. In light of the above discussion, the research model is as shown in Figure below.

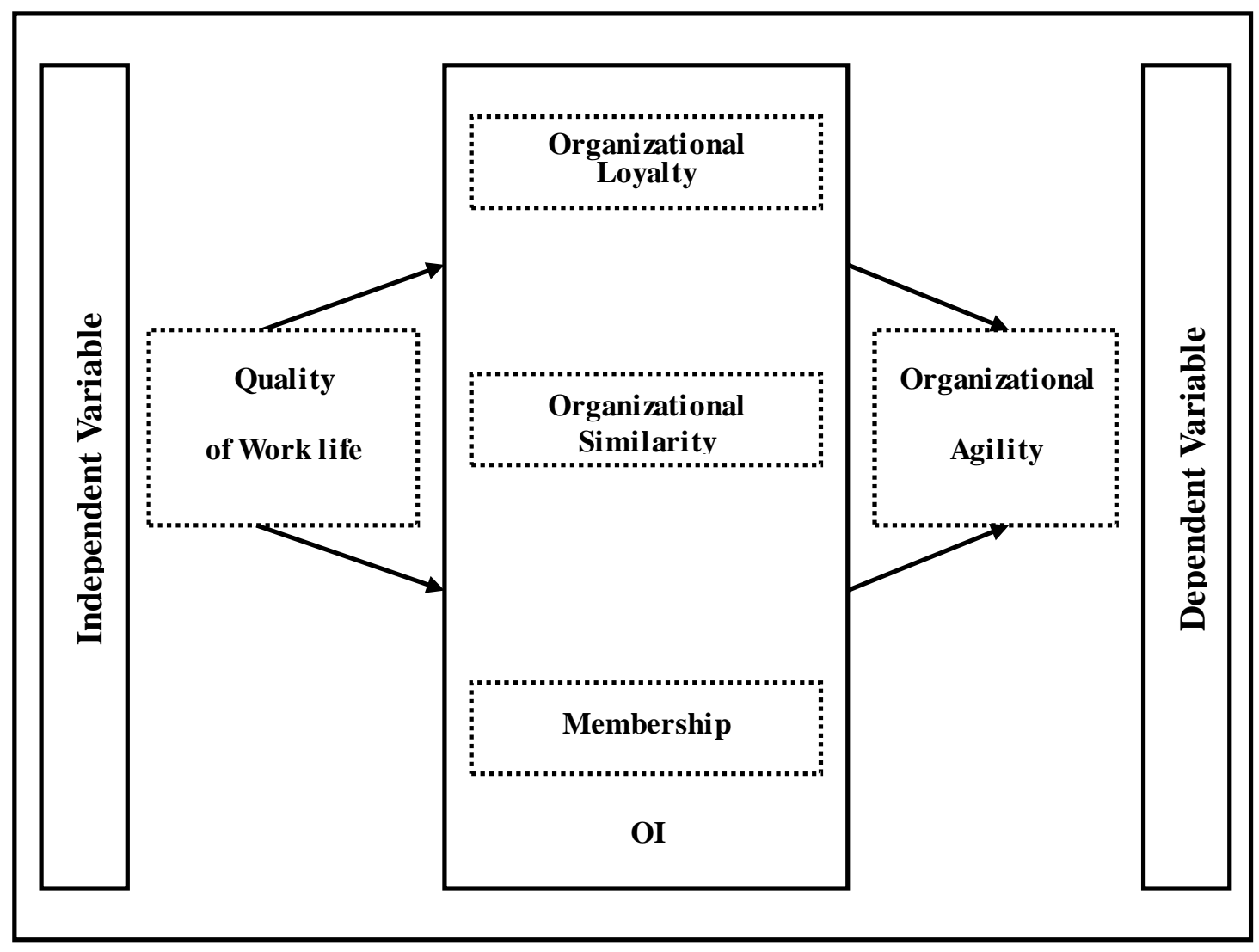

Figure 1. Proposed Comprehensive Conceptual Model

The research framework suggests that OI plays a significant role in the relationship between QWL and OA. OI is measured in terms of organizational loyalty, organizational similarity, and membership (Cheney, 1982).

QWL is measured in terms of wage justice, working conditions of the organization, opportunities for promotion, adherence to the principles of the organization, training and development of staff, social integration, work life and social responsibility (Timossi et al., 2008).

OA as measured consisted of sensing agility, decision-making agility and acting agility (Jaworski \& Kohli 1993).

\section{Research Questions}

The researcher found the research problem through two sources. The first source is to be found in previous studies, and it turns out that there is a lack in the number of literature reviews that dealt with the analysis of the relationship between QWL, OI, and OA at Menoufia University hospitals. This called for the researcher to test this relationship in the Egyptian environment. 
In light of the review of previous studies towards QWL, literature indicated that the QWL plays the mediating role between psychological capital and the intentions of leaving the organization (Kim et al., 2017). There is a significant correlation between QWL and organizational performance (Nayak et al., 2015). There is a relationship between QWL and career path (Bahrami et al., 2013). There is a significant relationship between QWL and organizational commitment (Farjal \& Varnous, 2013). There is a positive relationship between QWL and social responsibility (Tongo, 2013). In addition, there is a significant relationship between QWL and job satisfaction (Tabassum, 2012).

As for the OI, literature suggests that social responsibility and OI mediate the relationship between transformational leadership and organizational commitment (Erkutlu et al., 2016). Another study showed that OI significantly affects the relationship between mental integrity and organizational creativity (Liu et al., 2016). One of the studies has shown that customer orientation is a mediating variable in linking OI and job performance (He et al., 2015). Another study indicated that there is a significant relationship between leadership and OI (CeriBooms, 2010).

The literature review for OA indicated that OA plays an important role in influencing the organizational learning process (Mustafa et al., 2017). Another study showed that information technology works to achieve OA (Panda \& Rath, 2016). One study found that OA affects positively the performance of employees (Alhadid, 2016). Another study pointed to the need to pay attention to the organization's resource planning system, which leads to OA (Aburub, 2015).

The second source for the research problem is the pilot study, which was conducted in an interview with (30) employees in order to identify the relationship between QWL, OI and OA. The researcher found, through the pilot study, several indicators; notably the important and vital role that could be played by OI in interpreting the impact of QWL on OA at Menoufia University hospitals

As a result of the discussions given above, the research questions of this study are as follows:

Q1: What is the nature and extent of the relationship between QWL and OI at Menoufia University hospitals?

Q2: What is the extent of the relationship between QWL and OA at Menoufia University hospitals?

Q3: What is the nature of the relationship between OI and OA at Menoufia University hospitals?

Q4: What is the role of OI as a mediating variable between QWL and OA at Menoufia University hospitals?

\section{Research Hypotheses}

In the light of a review of previous studies towards QWL, literature has shown that there is a direct relationship between the QWL and OCB. There is an indirect relationship between emotional intelligence and OCB. QWL plays the mediating role between emotional intelligence and OCB (Alfonso et al., 2016). There is relationship between QWL and organizational commitment (Farid et al., 2015). There is a relationship between independent variables (QWL and job satisfaction) and dependent variable (OCB) (Kasraie et al., 2014). There is a significant correlation between SL and QWL (Bahrdmili et al., 2013). There is a positive relationship between QWL and organizational commitment (Parvar et al., 2013). There is a positive relationship QWL and job engagement (Kanten \& Sadullah, 2012).

As for OI, literature has shown that organizational justice plays an important role in influencing OI (Terzi et al., 2017). There is a positive correlation between OI and OCB (Callea et al., 2016). However, another study showed an indirect relationship between OI and job satisfaction (Karanika et al., 2015). One of the studies has shown that there is a statistically significant relationship between OCB and OI (Demir, 2015). In addition, there is a relationship between servant leadership and both OI and OCB. Another study found that there is a relationship between OI and OCB. A third study has shown that OI mediates the relationship between servant leadership and OCB (Vondey, 2010).

Finally, the literature review for OA has shown that is a relationship between OA and human resource effectiveness (Saha et al., 201). Another study points out that there is a direct relationship between OA and intellectual capital (Hajevar \& Kharazian, 201).

In addition, there is another study that indicated a positive relationship between organizational learning and OA. There is also a statistically significant relationship between OA and performance. In addition, there is a positive relationship between organizational learning and job performance. The study also indicated that OA plays the role of the intermediate variable between organizational learning and performance (Mashkani \& Khodadadi, 2016). Another study has indicated that there is a statistically significant relationship between OA and transformational leadership (Khoshlahn \& Ardabili, 2016). 
Another study indicates that there is a positive and statistically significant relationship between teamwork and OA (Dizari \& Garoosi, 2015).

Finally, another study indicated a statistically significant relationship between the dimensions of OA and organizational commitment (Chamanifard et al., 2015).

The following hypotheses were developed to test if there is significant correlation between QWL, OI and OA.

H1: QWL has no statistically significant effect on OI at Menoufia University hospitals.

$\mathrm{H} 2$ : There is no relationship between QWL and OA at Menoufia University hospitals.

H3: There is no statistical significant impact of OI on OA at Menoufia University hospitals .

H4: There is no statistical significant effect of OI as a mediating variable between QWL and OA at Menoufia University hospitals?

\section{Research Strategy}

\subsection{Population and Sample}

The population of the study included all employees at Menoufia University hospitals. The total population is 3307 employees. The random sampling was used for collecting the primary data as it was difficult to get all of the items of the research population, because of time limitations.

The stratified random sample was used while selecting items from the different categories of employees. The following equation determines the sampling size (Daniel, 1999):

$$
\mathrm{n}=\frac{N \times(Z)^{2} \times P(1-P)}{d^{2}(N-1)+(Z)^{2} \times P(1-P)}
$$

The number of samples obtained by 344 employees at Menoufia University Hospitals is presented in Table 1 .

Table 1. Distribution of the Sample Size on the Population

\begin{tabular}{|c|c|c|c|}
\hline $\begin{array}{c}\text { Job } \\
\text { Category } \\
\end{array}$ & Number & Percentage & $\begin{array}{c}\text { Size of } \\
\text { Sample } \\
\end{array}$ \\
\hline Physicians & 488 & $15 \%$ & $344 X 15 \%=52$ \\
\hline Nurses & 2141 & $65 \%$ & $344 \times 65 \%=224$ \\
\hline Administrative Staff & 678 & $20 \%$ & $344 \times 20 \%=68$ \\
\hline Total & 3307 & $100 \%$ & $344 \times 100 \%=344$ \\
\hline
\end{tabular}

Source: Personnel Department at Menoufia University, 2017

By using the lists of employees at the Staff Affairs Department, Menoufia University hospitals random choice of categories was attained. Table (2) illustrates the features of sample units.

Table 2. Characteristics of Items of the Sample

\begin{tabular}{|c|c|c|c|}
\hline & & Number & Percentage \\
\hline \multirow{4}{*}{ 1- Job Title } & Physicians & 110 & $40 \%$ \\
\hline & Nurses & 140 & $51 \%$ \\
\hline & Administrative & 25 & $9 \%$ \\
\hline & Total & 275 & $100 \%$ \\
\hline \multirow{3}{*}{ 2-Sex } & Male & 100 & $36 \%$ \\
\hline & Female & 175 & $64 \%$ \\
\hline & Total & 275 & $100 \%$ \\
\hline \multirow{3}{*}{ 3-Marital Status } & Single & 75 & $27 \%$ \\
\hline & Married & 200 & $73 \%$ \\
\hline & Total & 275 & $100 \%$ \\
\hline \multirow{4}{*}{ 4-Age } & Under 30 & 100 & $36 \%$ \\
\hline & From 30 to 45 & 120 & $44 \%$ \\
\hline & Above 45 & 50 & $20 \%$ \\
\hline & Total & 275 & $100 \%$ \\
\hline \multirow{3}{*}{ 5- Educational Level } & University & 225 & $82 \%$ \\
\hline & Post Graduate & 50 & $18 \%$ \\
\hline & Total & 275 & $100 \%$ \\
\hline \multirow{4}{*}{ 6- Period of Experience } & Less than 5 years & 100 & $36 \%$ \\
\hline & From 5 to 10 & 65 & $24 \%$ \\
\hline & More than 10 & 110 & $40 \%$ \\
\hline & Total & 275 & $100 \%$ \\
\hline
\end{tabular}




\subsection{Procedure}

The goal of this study was to identify the significant role of OI in the relationship between QWL and OA. A survey research method was used to collect data in this study. The questionnaire included four questions, relating to QWL, OI, OA and biographical information of employees at Menoufia University hospitals.

About 344 survey questionnaires were distributed by employing diverse modes of communication, such as in person and post. Multiple follow-ups yielded 275 statistically usable questionnaires. Survey responses were $80 \%$.

\subsection{Research Variables and Methods of Measuring}

The 33-item scale QWL section is based on Timossi et al., 2008. There were three items measuring adequate compensation, six items measuring working condition, three items measuring opportunity for growth, four items measuring constitutionalism, five items measuring opportunity for developing, four items measuring social integration, three items measuring working life, and five items measuring social responsibility. This scale is reliable and valid to use it and collect the data to measure QWL at Menoufia University hospitals.

The 23-item scale OI section is based on Cheney, 1982. There were seven items measuring organizational loyalty, seven items measuring organizational similarity and nine items measuring membership. This scale is reliable and valid to use it and collect the data to measure OI at Menoufia University hospitals.

The 15-item scale OA section is based on Jaworski \& Kohli 1993. There were three items measuring sensing agility, five items measuring decision-making agility, and seven items measuring acting agility. This scale is reliable and valid to use it and collect the data to measure OA at Menoufia University hospitals.

Responses to all items scales were anchored on a five (5) point Likert scale for each statement ranging from (5) "full agreement," (4) for "agree," (3) for "neutral," (2) for "disagree," and (1) for "full disagreement."

\subsection{Methods of Data Analysis and Testing Hypotheses}

The researcher has employed the following methods: (1) Cronbach's Alpha, (2) Multiple Regression Analysis (MRA), and (3) the statistical testing of hypotheses which includes F- test and T-test. They are found in SPSS.

Also, the researcher used the Analysis of Moment Structure (AMOS) to measure the direct and indirect effects of QWL on OA, as well as the measurement of the intermediate role of OI, through the indicators of conformity of alternative models on the one hand and the model that achieves these indicators on the other.

\section{Hypotheses Testing}

Before testing the hypotheses and research questions, descriptive statistics was performed to find out means and standard deviations of QWL, OI, and OA.

Table 3. The Mean and Standard Deviations of QWL, OI, and OA

\begin{tabular}{llcc}
\hline Variables & \multicolumn{1}{c}{ The Dimension } & Mean & $\begin{array}{c}\text { Standard } \\
\text { Deviation }\end{array}$ \\
& Adequate Compensation & 4.02 & 0.754 \\
& Working Condition & 3.68 & 0.851 \\
& Opportunity for Growth & 3.88 & 0.833 \\
& Constitutionalism & 3.86 & 0.835 \\
& Opportunity for Developing & 4.06 & 0.756 \\
& Social Integration & 3.99 & 0.783 \\
& Working Life & 3.91 & 0.911 \\
& Social Responsibility & 4.04 & 0.800 \\
& Total Measurement & $\mathbf{3 . 9 2}$ & $\mathbf{0 . 7 0 9}$ \\
& Organizational Loyalty & 3.76 & 0.953 \\
& Organizational Similarity & 3.48 & 0.841 \\
& Membership & 3.61 & 0.977 \\
& Total Measurement & $\mathbf{3 . 6 0}$ & $\mathbf{0 . 9 0 7}$ \\
& Sensing Agility & 3.65 & 1.03 \\
& Decision-Making Agility & 3.57 & 0.835 \\
& Acting Agility & 3.65 & 0.904 \\
\hline
\end{tabular}

According to Table (4), the first issue examined was the different facets of QWL. Most of the respondents identified the presence of adequate compensation $(M=4.02, S D=0.754)$, working condition $(M=3.68, S D=0.851)$, opportunity for growth $(M=3.88, S D=0.833)$, constitutionalism $(M=3.86, S D=0.835)$, opportunity for developing $(M=4.06, S D=0.756)$, social integration $(M=3.99, S D=0.783)$, working life $(M=3.91, S D=0.911)$, and social responsibility $(M=4.04, S D=0.800)$. 
The second issue examined was the different facets of OI. Most of the respondents identified the presence of organizational loyalty $(M=3.76, S D=0.953)$, organizational similarity $(M=3.48, S D=0.841)$, and membership $(M=3.61, S D=0.977)$.

The third issue examined was the different facets of OA. Most of the respondents identified the presence of sensing agility $(M=3.65, S D=1.03)$, decision-making agility $(M=3.57, S D=0.835)$, and acting agility $(M=3.65, S D=0.904)$.

\subsection{Evaluating Reliability}

Table 4 shows the reliability results for QWL, OI and OA. All items had alphas above 0.70 and were therefore excellent, according to Langdridge's (2004) criteria.

Table 4. Reliability of QWL, OI and OA

\begin{tabular}{clcc}
\hline Variables & \multicolumn{1}{c}{ The Dimension } & $\begin{array}{c}\text { Number of } \\
\text { Statement }\end{array}$ & ACC \\
\hline \multirow{2}{*}{ QWL } & Adequate Compensation & $\mathbf{3}$ & 0.621 \\
& Working Condition & $\mathbf{6}$ & 0.793 \\
& Opportunity for Growth & $\mathbf{3}$ & 0.791 \\
& Constitutionalism & $\mathbf{4}$ & 0.824 \\
& Opportunity for Developing & $\mathbf{5}$ & 0.814 \\
& Social Integration & $\mathbf{4}$ & 0.707 \\
& Working Life & $\mathbf{3}$ & 0.729 \\
& Social Responsibility & $\mathbf{5}$ & 0.801 \\
& Total Measurement & $\mathbf{3 3}$ & $\mathbf{0 . 9 5 9}$ \\
& Organizational Loyalty & $\mathbf{7}$ & 0.935 \\
& Organizational Similarity & $\mathbf{7}$ & 0.942 \\
& Membership & $\mathbf{9}$ & 0.970 \\
& Total Measurement & $\mathbf{2 3}$ & $\mathbf{0 . 9 8 3}$ \\
& Sensing Agility & $\mathbf{3}$ & 0.927 \\
& Decision-Making Agility & $\mathbf{5}$ & 0.839 \\
& Acting Agility & $\mathbf{7}$ & 0.921 \\
\hline
\end{tabular}

According to Table (4), the 33 items of QWL are reliable because the Cronbach's Alpha is 0.959. The adequate compensation, which consists of 3 items, is reliable because the Cronbach's Alpha is 0.621 . The 6 items related to working condition are reliable because the Cronbach's Alpha is 0.793 while the 3 items of opportunity for growth are reliable because the Cronbach's Alpha is 0.791 . The constitutionalism, which consists of 4 items, is reliable because the Cronbach's Alpha is 0.824 . The 5 items related to opportunity for developing are reliable because the Cronbach's Alpha is 0.814 , while the 4 items of social integration are reliable because the Cronbach's Alpha is 0.707, while the 3 items of working life are reliable because the Cronbach's Alpha is 0.729 . Social responsibility, which consists of 5 items, is reliable because the Cronbach's Alpha is 0.801 . Thus, the internal consistency of QWL can be acceptable.

In connection with Table (4), the 23 items of OI are reliable because the Cronbach's Alpha is 0.983 . The organizational loyalty, which consists of 7 items, is reliable because the Cronbach's Alpha is 0.935 . The 7 items related to organizational similarity are reliable because Cronbach's Alpha is 0.942 , while the last nine-item (membership) is reliable because the Cronbach's Alpha is 0.970 . Thus, the reliability of OI can be acceptable.

Table (4) presents the reliability of OA. The reliabilities of sensing agility, decision-making agility and acting agility are generally higher. The 15 items of OA are reliable because the ACC is 0.961 . Sensing agility, which consists of 3 items, is reliable because the ACC is 0.927 . Decision-making agility, which consists of 5 items, is reliable because the ACC is 0.839 . Acting agility, which consists of 7 items, is reliable because the ACC is 0.921 . Thus, the internal consistency of OAcan be acceptable.

\subsection{The Correlation between the Research Variables}

Table 5. Means, Standard Deviations and Intercorrelations among Variables

\begin{tabular}{cccccc}
\hline Variables & Mean & $\begin{array}{c}\text { Std. } \\
\text { Deviation }\end{array}$ & QWL & OI & OA \\
\hline Quality of Work Life & 3.92 & 0.709 & 1 & & \\
Organizational Identification & 3.60 & 0.907 & $0.711^{* *}$ & 1 & \\
Organizational Agility & 3.63 & 0.879 & $0.701^{* *}$ & $0.933^{* *}$ & 1 \\
\hline
\end{tabular}

Table (5) shows correlation coefficients between the research variables, and results indicate the presence of significant correlation between variables ( $Q W L, O I$ and $\mathrm{OA})$. The level of $\mathrm{QWL}$ is high (Mean=3.92; $\mathrm{SD}=0.709$ ), while $\mathrm{OI}$ is high (Mean=3.60; $\mathrm{SD}=0.907)$ which led to higher $\mathrm{OA}(\mathrm{Mean}=3.63 ; \mathrm{SD}=0.879)$. 
Table (5) reveals the correlation between QWL and OI $(\mathrm{R}=0.711 ; \mathrm{P}<0.01)$, which means that the high level of QWL leads to higher OI. The table shows the correlation between $\mathrm{OI}$ and $\mathrm{OA}(\mathrm{R}=0.933 ; \mathrm{P}<0.01)$ and this shows that the high level of OI contributes to mitigation of feelings of OA. Finally, Table (5) refers to the correlation between $\mathrm{QWL}$ and $\mathrm{OA}(\mathrm{R}=0.701 ; \mathrm{P}<0.01)$ implying that the high level of QWLincreases OA.

\subsection{Quality of Work Life and Organizational Identification}

The relationship between QWL and OI is determined. The first hypothesis to be tested is:

\section{H1: QWL has no statistically significant effect on OI at Menoufia University hospitals.}

Based on the Table (6), there is a positive correlation between QWL and OI. The correlation between QWL (adequate compensation) and OI is 0.68 . For QWL (working condition) and OI, the value is 0.57 whereas QWL (opportunity for growth) and OI show a correlation value of 0.53 . Also, the correlation between QWL (constitutionalism) and QWL is 0.50. For QWL (opportunity for developing) and OI, the value is 0.65 , whereas QWL (social integration) and OI show a correlation value of 0.66 . For QWL (working life) and OI, the value is 0.68 . Finally, the correlation between QWL (social responsibility) and OI is 0.69 . The overall correlation between QWL and OI is 0.71 .

Table 6. Correlation Matrix between QWL and OI

\begin{tabular}{|c|c|c|c|c|c|c|c|c|c|}
\hline Variables & 1 & 2 & 3 & 4 & 5 & 6 & 7 & 8 & 9 \\
\hline $\begin{array}{l}\text { Adequate } \\
\text { Compensation }\end{array}$ & 1 & & & & & & & & \\
\hline Working Condition & $0.65^{* *}$ & 1 & & & & & & & \\
\hline $\begin{array}{l}\text { Opportunity for } \\
\text { Growth }\end{array}$ & $0.77^{* *}$ & $0.49^{* *}$ & 1 & & & & & & \\
\hline Constitutionalism & $0.77^{* *}$ & $0.53^{* *}$ & $0.96^{* *}$ & 1 & & & & & \\
\hline $\begin{array}{l}\text { Opportunity for } \\
\text { Developing }\end{array}$ & $0.90^{* *}$ & $0.68^{* *}$ & $0.74^{* *}$ & $0.78^{* *}$ & 1 & & & & \\
\hline Social Integration & $0.83^{* *}$ & $0.81^{* *}$ & $0.47^{* *}$ & $0.49^{* *}$ & $0.84^{* *}$ & 1 & & & \\
\hline $\begin{array}{l}\text { Working } \\
\text { Life }\end{array}$ & $0.84^{* *}$ & $0.80^{* *}$ & $0.43^{* *}$ & $0.45^{* *}$ & $0.77^{* *}$ & $0.95^{* *}$ & 1 & & \\
\hline Social Responsibility & $0.85^{* *}$ & $0.77^{* *}$ & $0.45^{* *}$ & $0.47^{* *}$ & $0.83^{* *}$ & $0.96^{* *}$ & $0.95^{* *}$ & 1 & \\
\hline $\begin{array}{l}\text { Organizational } \\
\text { Identification }\end{array}$ & $0.68^{* *}$ & $0.57^{* *}$ & $0.53^{* *}$ & $0.50^{* *}$ & $0.65^{* *}$ & $0.66^{* *}$ & $0.68^{* *}$ & $0.68^{* *}$ & 1 \\
\hline
\end{tabular}

Note: ** Correlation is significant at 0.01 level.

Table 7. MRA Results for QWLand OI

\begin{tabular}{|c|c|c|c|}
\hline $\begin{array}{c}\text { The Variables of } \\
\text { QWL }\end{array}$ & Beta & $\mathbf{R}$ & $\mathbf{R}^{2}$ \\
\hline 1. Adequate Compensation & 0.313 & 0.686 & 0.470 \\
\hline 2. Working Condition & 0.026 & 0.578 & 0.334 \\
\hline 3. Opportunity for Growth & $0.706^{* *}$ & 0.530 & 0.280 \\
\hline 4. Constitutionalism & $0.395^{*}$ & 0.502 & 0.525 \\
\hline 5. Opportunity for De veloping & $0.255^{*}$ & 0.655 & 0.429 \\
\hline 6. Social Integration & $0.530^{* *}$ & 0.661 & 0.436 \\
\hline 7. Working Life & $0.696^{* *}$ & 0.683 & 0.466 \\
\hline 8. Social Responsibility & $0.469^{* *}$ & 0.682 & 0.465 \\
\hline - $\mathrm{MCC}$ & & 0.747 & \\
\hline - DC & & 0.558 & \\
\hline - Calculated F & & 42.043 & \\
\hline - Degree of Freedom & & 8,266 & \\
\hline - Indexed F & & 2.511 & \\
\hline - Level of Significance & & 0.00 & \\
\hline$* * \mathbf{P}<.01 \quad * \mathbf{P}<.05$ & & & \\
\hline
\end{tabular}

As Table (7) proves, the MRA resulted in the R of 0.747 demonstrating that the independent variables of QWL construe OI significantly. Furthermore, the value of R square, independent variables of QWL can explain 55\% of the total factors in OI level. Hence, $45 \%$ are explained by the other factors. Therefore, there is enough empirical evidence to reject the null hypothesis.

\subsection{Quality of Work Life and Organizational Agility}

The relationship between QWL and OA is determined. The second hypothesis to be tested is:

H2: There is no relationship between $Q W L$ and $O A$ at Menoufia University hospitals. 
Table 8. Correlation Matrix between QWL and OA

\begin{tabular}{|c|c|c|c|c|c|c|c|c|c|}
\hline Variables & 1 & 2 & 3 & 4 & 5 & 6 & 7 & 8 & 9 \\
\hline $\begin{array}{l}\text { Adequate } \\
\text { Compensation }\end{array}$ & 1 & & & & & & & & \\
\hline Working Condition & $0.65^{* *}$ & 1 & & & & & & & \\
\hline $\begin{array}{l}\text { Opportunity for } \\
\text { Growth }\end{array}$ & $0.77^{* *}$ & $0.49^{* *}$ & 1 & & & & & & \\
\hline Constitutionalism & $0.77^{* *}$ & $0.53^{* *}$ & $0.96^{* *}$ & 1 & & & & & \\
\hline $\begin{array}{l}\text { Opportunity for } \\
\text { Developing }\end{array}$ & $0.90^{* *}$ & $0.68^{* *}$ & $0.74^{* *}$ & $0.78^{* *}$ & 1 & & & & \\
\hline Social Integration & $0.83^{* *}$ & $0.81^{* *}$ & $0.47^{* *}$ & $0.49^{* *}$ & $0.84^{* *}$ & 1 & & & \\
\hline $\begin{array}{l}\text { Working } \\
\text { Life }\end{array}$ & $0.84^{* *}$ & $0.80^{* *}$ & $0.43^{* *}$ & $0.45^{* *}$ & $0.77^{* *}$ & $0.95^{* *}$ & 1 & & \\
\hline Social Responsibility & $0.85^{* *}$ & $0.77^{* *}$ & $0.45^{* *}$ & $0.47^{* *}$ & $0.83^{* *}$ & $0.96^{* *}$ & $0.95^{* *}$ & 1 & \\
\hline $\begin{array}{l}\text { Organizational } \\
\text { Agility }\end{array}$ & $0.67^{* *}$ & $0.56^{* *}$ & $0.57^{* *}$ & $0.54^{* *}$ & $0.64^{* *}$ & $0.64^{* *}$ & $0.64^{* *}$ & $0.63^{* *}$ & 1 \\
\hline
\end{tabular}

Note: ** Correlation is significant at 0.01 level.

Based on the Table (8), there is a positive correlation between QWL and OA. The correlation between QWL (adequate compensation) and OA is 0.67 . For QWL (working condition) and OA, the value is 0.56 whereas QWL (opportunity for growth) and $\mathrm{OA}$ show a correlation value of 0.56 . Also, the correlation between QWL (constitutionalism) and QWL is 0.54. For QWL (opportunity for developing) and OA, the value is 0.64 whereas QWL (social integration) and OA show a correlation value of 0.64. For QWL (working life) and OA, the value is 0.64 . Finally, the correlation between QWL(social responsibility) and OA is 0.63 . The o verall correlation between QWL and OA is 0.70 .

Table 9. MRA Results for QWLand OA

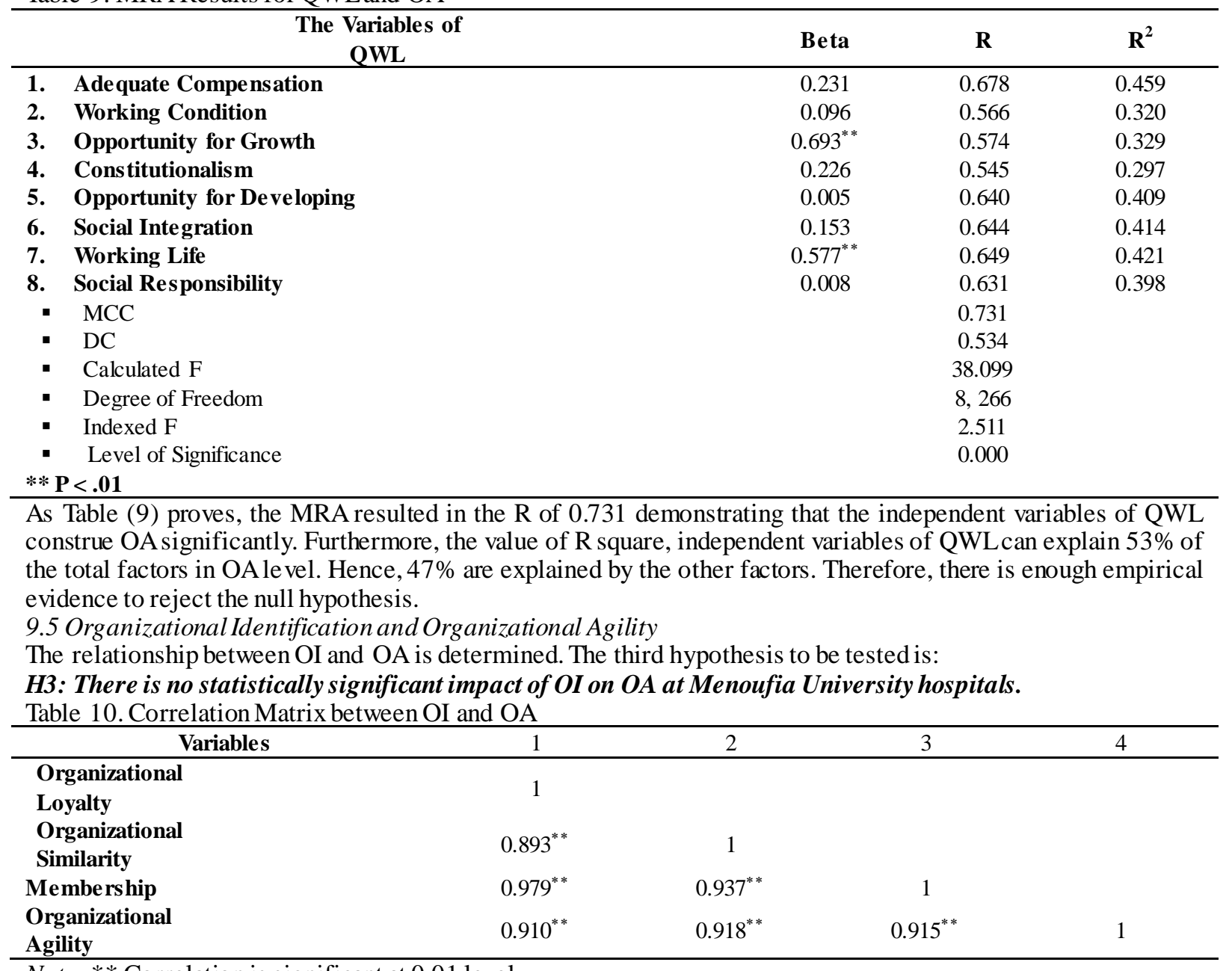

Note: ** Correlation is significant at 0.01 level. 
Based on the Table (10), there is a positive correlation between OI and OA. The correlation between OI (organizational loyalty) and OA is 0.910 . For OI (organizational loyalty) and OA, the value is 0.918 , whereas OI (membership) and OA show correlation value of 0.915 . The overall correlation between OI and OA is 0.93 .

Table 11. MRA Results for OI and OA

\begin{tabular}{|c|c|c|c|}
\hline $\begin{array}{c}\text { The Variables of } \\
\text { OI }\end{array}$ & Beta & $\mathbf{R}$ & $\mathbf{R}^{2}$ \\
\hline $\begin{array}{l}\text { 1. } \\
\text { Organizational } \\
\text { Loyalty }\end{array}$ & $0.711^{* *}$ & 0.910 & 0.828 \\
\hline $\begin{array}{l}\text { 2. Organizational } \\
\text { Similarity }\end{array}$ & $0.641^{* *}$ & 0.918 & 0.842 \\
\hline 3. Membership & $0.381^{* *}$ & 0.95 & 0.837 \\
\hline $\begin{array}{ll}\text { - } & \text { MCC } \\
\text { - } & \text { DC } \\
\text { - } & \text { Calculated F } \\
\text { - } & \text { Degree of Freedom } \\
\text { : } & \text { Level of Significance } \\
* * \mathbf{P}<\mathbf{0 1}\end{array}$ & & $\begin{array}{c}0.942 \\
0.886 \\
705.474 \\
3,271 \\
3.78 \\
0.00\end{array}$ & \\
\hline
\end{tabular}

As Table (11) proves, the MRA resulted in the R of 0.942 demonstrating that the independent variables of OI construe OA significantly. Furthermore, the value of R square, independent variables of OI can explain $88 \%$ of the total factors in OA level. Hence, $12 \%$ are explained by the other factors. Therefore, there is enough empirical evidence to reject the null hypothesis.

9.6 OI as a Mediating Variable of the Relationship between QWL and OA

The statistical significant effect of OI as a mediating variable of the relationship between QWL and OA is determined. The fourth hypothesis to be tested is:

H4: There is no significant effect of OI as a mediating variable of the relationship between $Q W L$ and OA at Menoufia University hospitals.

The study of the effect of the independent variable on the dependent variable through the intermediate variable is an important subject in social studies (Holmbeck, 1997). OI plays the mediating role in the relationship between QWL and OA through testing three different models. This can be illustrated as follows:

\subsubsection{Full Direct Effects Model}

This model is based on the fact that QWL directly affects the OA. This is in addition to the direct relationship between the mediating variable (OI) and the dependent variable (OA). The structural model of the direct and complete effect of the search variables can be illustrated by the following diagram:

Figure 2. The Structural Model of the Direct and Complete Effect of the Search Variables

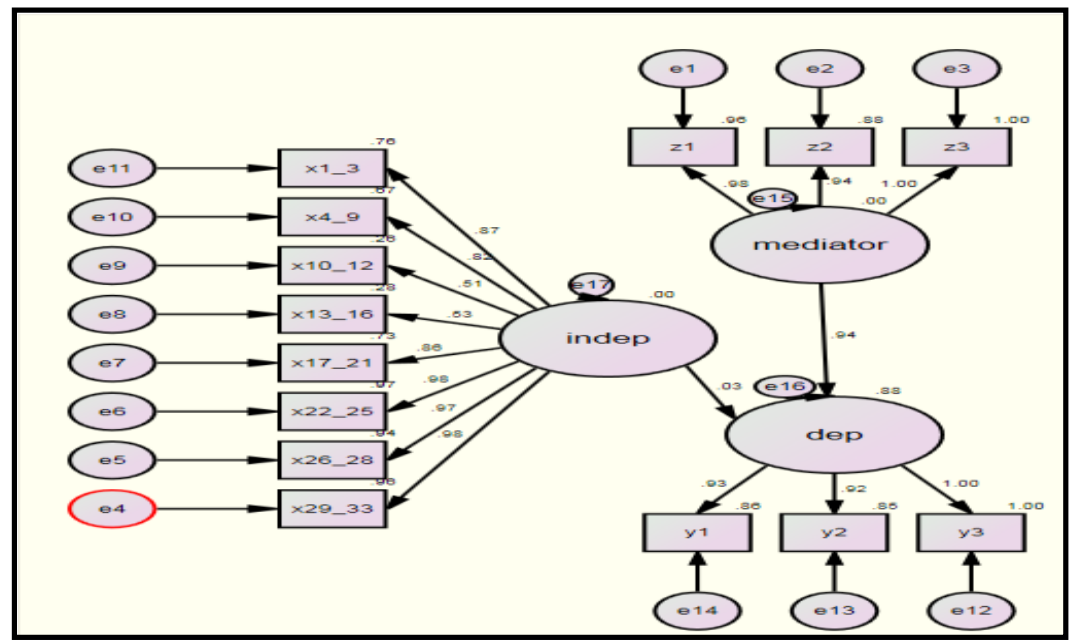

Source: The researcher based on the outputs of AMOS, V.23, 2015.

- Independent Variable is $Q W L$.

- Mediating Variable is OI.

- Dependent Variable is OA. 
In light of the previous figure, there is a direct effect of QWL on OA, and the direct effect of OI on OA. The correlation quality indicators of the direct and complete impact model can be illustrated in the following table:

Table 12. Match Quality Indicators for the Direct Impact Model of Search Variables

\begin{tabular}{lcc}
\hline \multicolumn{1}{c}{ Test the Quality of the Model } & Test Value & Acceptance $^{\text {Condition }}{ }^{(*)}$ \\
\hline $\mathrm{X}^{2} /$ Degree of freedom & 26.0 & $\left(\mathrm{X}^{2} / \mathrm{df}\right)<5$ \\
P. value & 0.000 & $\mathrm{P}>0.5$ \\
Goodness of fit Index (GFI) & 0.693 & $\mathrm{GFI}>0.90$ \\
Tuker-Lewis Index (TLI) & 0.593 & TLI $>0.9$ \\
Comparative Fit Index (CFI) & 0.709 & CFI $>0.95$ \\
Normed Fit Index (NFI) & 0.704 & NFI $>0.90$ \\
Incremental Fit Index (IFI) & 0.710 & IFI $>0.9$ \\
\hline
\end{tabular}

(*) Daire et al., 2008

Source: The researcher based on the outputs of AMOS, V.23, 2015

In light of the above-mentioned indicators, it was found that QWL had an effect on the OAon the one hand, and the direct effect of $\mathrm{OI}$ on the OA on the other hand. This decision was based on the value of (X2/degrees of freedom), the value of $(\mathrm{P})$, and the indicators of GFI, TLI, CFI, NFI, and IFI.

\subsubsection{Full Mediated Model}

This model is based on the fact that OI mediates the relationship between QWLand OA fully. The structural model of the full mediation of the search variables can be illustrated by the following form:

Figure 3. Structural Model for Full Mediation of Search Variables

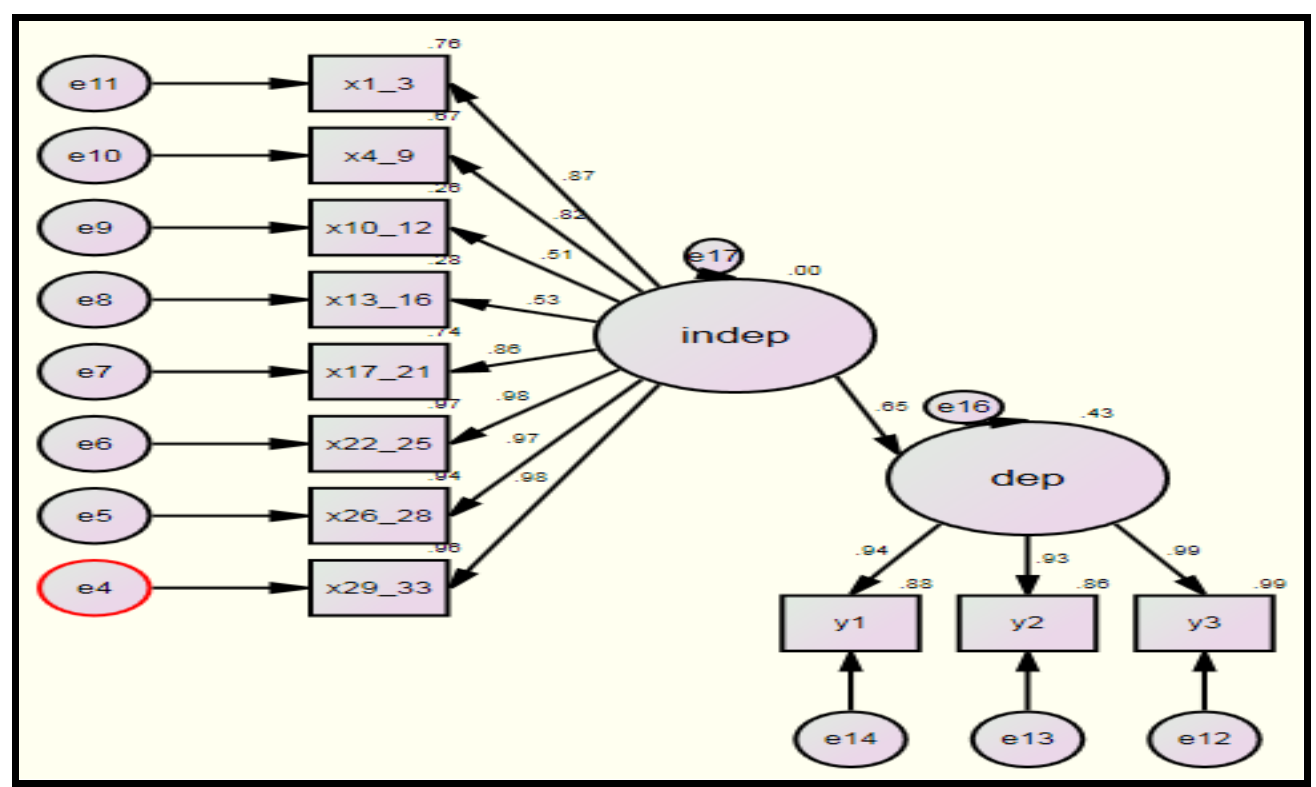

Source: The researcher based on the outputs of AMOS, V.23, 2015

In light of the previous figure, it was found that the independent variable (QWL) had an impact on the dependent variable (OA). This decision was based on the value of (X2/ degrees of freedom), the value of $(\mathrm{P})$, and the indicators of GFI, TLI, CFI, NFI, and IFI.

Table 13. Match Quality Indicators for the Direct Impact Model of Search Variables

\begin{tabular}{lcc}
\hline \multicolumn{1}{c}{ Test the Quality of the Model } & Test Value & Acceptance $^{\text {Condition }}{ }^{(*)}$ \\
\hline $\mathrm{X}^{2} /$ Degree of freedom & 29.0 & $\left(\mathrm{X}^{2} / \mathrm{df}\right)<5$ \\
P. value & 0.000 & $\mathrm{P}>0.5$ \\
Goodness of fit Index (GFI) & 0.580 & GFI $>0.90$ \\
Tuker-Lewis Index (TLI) & 0.538 & TLI $>0.9$ \\
Comparative Fit Index (CFI) & 0.699 & $\mathrm{CFI}>0.95$ \\
Normed Fit Index (NFI) & 0.695 & $\mathrm{NFI}>0.90$ \\
Incremental Fit Index (IFI) & 0.700 & IFI $>0.9$ \\
\hline
\end{tabular}

$(*)$ Daire et al., 2008

Source: The researcher based on the outputs of AMOS, V.23, 2015 


\subsubsection{Partial Mediated Model}

This model is based on the indirect effect of the independent variable (QWL) and the dependent variable (OA) through the intermediate variable (OI).

Figure 4. The Structural Model of the Search Variables

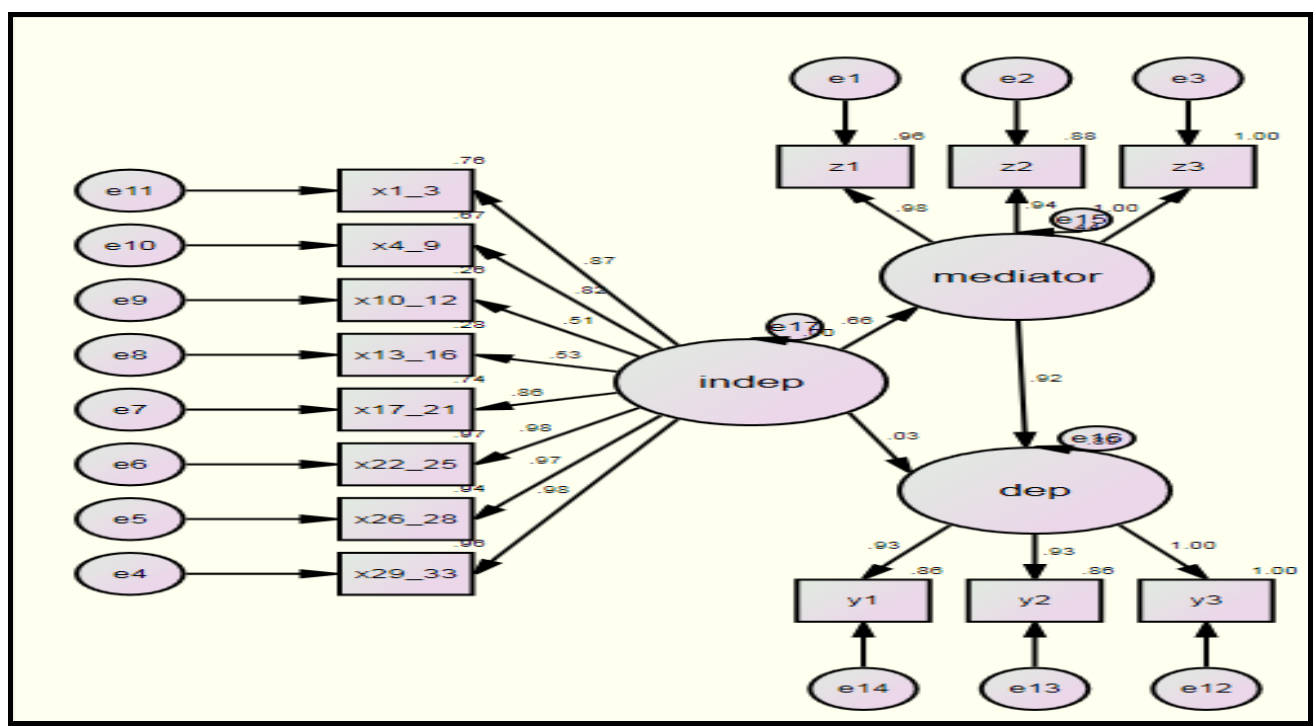

Source: The researcher based on the outputs of AMOS, V.23, 2015

- Independent Variable is $Q W L$.

- Mediating Variable is OI.

- Dependent Variable is OA.

It is clear that there is an indirect influence between the QWL on OA and OI. The different indicators of the quality of the partial mediation model can be explained in the following table:

Table 14. Match Quality Indicators for the Direct Impact Model of Search Variables

\begin{tabular}{lcc}
\hline \multicolumn{1}{c}{ Test the Quality of the Model } & Test Value & Acceptance $^{\text {Condition }}{ }^{(*)}$ \\
\hline $\mathrm{X}^{2}$ / Degree of freedom & 27.0 & $\left(\mathrm{X}^{2} / \mathrm{df}\right)<5$ \\
P. value & 0.00 & $\mathrm{P}>0.5$ \\
Goodness of fit Index (GFI) & 0.651 & GFI $>0.90$ \\
Tuker-Lewis Index (TLI) & 0.615 & TLI $>0.9$ \\
Comparative Fit Index (CFI) & 0.728 & $\mathrm{CFI}>0.95$ \\
Normed Fit Index (NFI) & 0.723 & NFI $>0.90$ \\
Incremental Fit Index (IFI) & 0.729 & IFI $>0.9$ \\
\hline
\end{tabular}

$(*)$ Daire et al., 2008

Source: The researcher based on the outputs of AMOS, V.23, 2015

Accordingly, it should be noted that all the previous indicators confirm that all model estimates are significant, which shows that there is an indirect relationship between QWL and OA through OI; that is, OI plays the role of partial mediation between QWL and OA at Menoufia University hospitals. In the light of the above, the Sobel test was carried out in order to measure the indirect effects of QWL on OAunder OI. Therefore, the previous results are not significant unless after testing Sobel. The Sobel test depends on the value of $Z$ value. If the $Z$ value is greater than 1.96 we conclude that the model is an intermediate variable model, that is, the indirect effect is true and vice versa if $\mathrm{Z}$ value is less than 1.96 . This can be illustrated by the following table:

Table 15. Sobel Test

\begin{tabular}{lc}
\hline \multicolumn{1}{c}{ Significance Indirect Effect } & Test Value \\
\hline Effect Degree & 0.7734 \\
Standard Error & 0.0537 \\
The Value of Calculated Z & 14.4046 \\
Degree of Freedom & 2.272 \\
The Value of Indexed Z & 1.96 \\
P. value & 0.000 \\
\hline
\end{tabular}

Source: The researcher based on the outputs of AMOS, V.23, 2015 
In light of the previous table, there is a significant effect of OI on the relationship between QWL and OA. According to the above-mentioned results, it was found that that there is a significant effect of QWL on OA through OI, that is, OI plays the mediating role on the relationship between QWL and OA. This decision was based on the value of the $\mathrm{X}^{2} /$ degrees of freedom, the value of P, the GFI, TLI, CFI, NFI, IFI, and Sobel tests.

\section{Research Results}

By reviewing the results of descriptive analysis of the data on which the study was based and testing the hypotheses of the research, the study reached a set of results as follows:

1. There is a positive impact of QWL on OI at Menoufia University Hospitals. The multiple regression model showed that there is an effect of QWL as an independent variable on OI as a dependent variable at Menoufia University hospitals. This finding is consistent with the study by Arslan \& Akkas, 2015, which concluded that QWL plays an important role in achieving OI. The study also noted that satisfaction with the social dimension as a QWL dimensions plays an important role in the development of the process of OI. In addition, both satisfaction with service and similarity have a positive impact on satisfaction with QWL. Therefore, managers must be concerned primarily with improving social satisfaction, which leads to higher levels of satisfaction with the service offered.

2. There is a positive impact of QWL on OA. The multiple regression model showed that there is an effect of QWL as an independent variable on OA as a dependent variable at Menoufia University hospitals. This finding is consistent with the study by Nafei, 2016, in which OA plays an important role in improving QWL. The study also indicates that QWL can be improved through the sensing agility, decision-making, as well as acting agility.

3. There is a positive effect of OI on OA, after the multiple regression model showed that there is an effect of $\mathrm{OI}$ as an independent variable on OA as a dependent variable at Menoufia University Hospitals.

4. Under the full direct effects Model, there was a direct effect of QWL on OA and the direct effect of the variable (OI) on OA. In other words, there is a partial effect of OI on the relationship between QWL and OA at Menoufia University hospitals, that is, OA plays a partial role in the relationship between QWL and OA at Menoufia University Hospitals.

5. Under the full Mediated Model, it was found that there is a direct effect of QWL on OA. In other words, OI mediates the relationship between QWL and OA at Menoufia University hospitals.

6. Under the Partially Mediated Model, it was found that there is an indirect impact between QWL and OA through OI as an intermediate variable. In other words, OI plays the role of partial mediation in the relationship between QWL and OA at Menoufia University hospitals.

\section{Conclusion}

This section includes (1) the research recommendation, and (2) the research limitations and future research.

\subsection{Recommendations}

The most important of these recommendations can be summarized as follows:

1. Re-studying and structuring of the system of wages in the hospital in a way that allows them to get the appropriate return for their efforts. This can be achieved through the following:

- Increasing rewards in the hospital to meet the low wages and be commensurate with the individual effort in the hospital. This can be achieved by increasing the resources of the hospital from the diversity and multiplicity of services provided to members of the community, in providing the service.

- The need to pay attention to the application of the principle of reward and punishment in the hospital in terms of the item of wages and bonuses, as a group of employees receive financial rewards much higher than the effort and vice versa.

- The need to improve the wages of all employees in the hospital. This can be done by multiplicity and diversity of services provided by the hospital to the members of the community in a way that increases the self resources or by addressing the concerned parties to raise wages.

2. Providing a safe and healthy work environment for all employees in different educational hospitals. This can be achieved through the following:

- The need for hospital officials to take care of the physical conditions of the work in terms of lighting, ventilation and cleanliness.

- The need to provide safety means and different protection methods for the hospital staff or patients. 
3. Concern for achieving the welfare of hospital staff and improving the quality of the career in terms of providing promotion opportunities and being objective in accordance with specific standards and controls.

4. Activation of training programs but not to specific categories. Training includes all aspects of technical, humanitarian and moral; the training periods are continuing, as training plays an important role in raising morale and satisfaction of employees. This increases the staff opportunities for promotion and reveals their abilities and skills.

5. Involvement of hospital staff in the decision-making process, in view of the nature and sensitivity of work in the hospital, which concerns the lives of citizens. That needs a large area of freedom to make decisions; employees feel they are making plans and programs themselves for themselves, in organizational symmetry.

6. Activating complaints and suggestions box in the hospital in a way that helps employees to express their opinions and suggestions, which leads to improving the quality of service provided by the hospital.

7. Abiding by the principles and rules governing the nature of work in the hospital for all individuals, but not favor and courtesy of some individuals at the expense of others.

8. Development and utilization of human capacities in the hospital. This can be done by increasing the knowledge of its employees by encouraging them to attend training courses or by completing their higher studies, which leads to multiple sources of knowledge.

9. The importance of achieving social integration in the hospital through the need to respect and appreciate the ideas and opinions of all staff in the hospital, to spread the spirit of cooperation and mutual respect among all personnel working in the hospital of different job categories.

10. Emphasizing the absence of a negative impact on the work life on the total life area of the personnel working in the hospital. This can be done by attention to the schedule of rest so as not to adversely affect the quality of service provided, and that there is no increase in the volume of tasks and work entrusted to an individual in the hospital in a way that negatively affects his personal life.

11. Emphasizing the social responsibility of the hospital by improving the mental image of the hospital members of the community, to develop and improve the quality of service provided by the hospital to members of the community.

12. The officials in the hospital should pay more attention to the staff, through the identification of their wishes and needs and trying to realize them commensurate with their objectives in order to improve the process of OI.

\subsection{Limitations and Future Research}

There are some limitations of this study. Firstly, the data was collected from employees in one country, Egypt. Therefore, the generalization of the results must be made with caution. Secondly, the findings may not be generalized to other organizations in Egypt. Thirdly, a small sample size is used. Fourthly, the females were more than males because the policy of the hospital prefer to select the females because they are more patient than men in dealing with patients

There are several areas for future research. They are (1) the relationship between OI and OCB, (2) the mediating variables which link OI to OA, (3) similar studies should be undertaken in other organizations in Egypt, using a larger sample size, (4) future studies should look at a comparative study of another sector such as education, and tourism, and (5) future studies should examine the relationship between OI and QWL.

\section{References}

Aburub, F. (2015). Impact of ERP Systems Usage on Organizational Agility. Information Technology \& People, 28(3), 570-588. https://doi.org/10.1108/ITP-06-2014-0124

Ahuja, N. (2015). Quality of Work Life: Research Paper. Paripex-Indian Journal of Research, 4, 3-5.

Alfonso, L., Zenasni, F., Hodzic, S., \& Ripoll, P. (2016). Understanding the Mediating Role of Quality of Work Life on the Relationship between Emotional Intelligence and Organizational Citizenship Behaviors. Psychological Reports, 118(1), 107-127. https://doi.org/10.1177/0033294115625262

Alhdid, A. (2016). The Effects of Organizational Agility on Organizational Performance. International Review of Management and Business Research, 5(1), 273-278.

Allen, G., Attoh, P., \& Gong, T. (2017). Transformational leadership and affective organizational commitment: mediating roles of perceived social responsibility and organizational identification. Social Responsibility 
Journal, 13(3), 585-600. https://doi.org/10.1108/SRJ-11-2016-0193

Ardichvili, A., Cardozob, R., \& Rayc, S. (2003). A Theory of Entrepreneurial Opportunity Identification and Development. Journal of Business Venturing, 18, 105. https://doi.org/10.1016/S0883-9026(01)00068-4

Arslan, S., \& Akkas, O. A. (2014). Quality of College Life (QCL) of Students in Turkey: Students' Life Satisfaction and Identification. Social indicators research, 115(2), 869-884. https://doi.org/10.1007/s11205-013-0235-9

Bahrami, A., Aslani, G., Abdollahie, B., \& Torabi, N. (2013). A Study on the Relation between Quality of Work Life and four Career Anchors among the Personnel of Esfahan's Iron Foundry Organization. Procedia-Social and Behavioral Sciences, 83, 208-213. https://doi.org/10.1016/j.sbspro.2013.06.041

Burtson, L., Stichler, F. (2010). Nursing Work Environment and Nurse Caring. Journal of Advanced Nursing, 66(8), 1819-1831. https://doi.org/10.1111/j.1365-2648.2010.05336.x

Ceri-Booms, M. (2010). An Empirical Study on Transactional and Authentic Leaders: Exploring the Mediating Role of trust in leader on Organizational Identification, the Business Review. Cambridge, 14(2), 235-243.

Chamanifard, R., Nikpour, A., Chamanifard, S., \& Nobarieidishe, S. (2015), Impact of Organizational Agility Dimensions on Employee's Organizational Commitment in Foreign Exchange Office of Tejaret Bank, Iran . European online Journal of Natural and Social Science, 4(1), 199-207.

Cllea, A., Urbini, F., \& Chirumbolo, A. (2016). The Mediating role of Organizational Identification in the Relationship between Qualitative Job Insecurity, OCB and Job Performance. Journal of Management Development, 35(1), 735-746. https://doi.org/10.1108/JMD-10-2015-0143

Daire, H., Joseph, C., \& Michael, R. M. (2008). Structural Equation Modelling. Journal of Business Research Methods, 6(1).

David, F., (2009). Strategic Management- Concepts and Cases, 12th ed., Prentice-Hill Pearson Education International Inc. U.S.A. P. 46.

Demir, K. (2015). Teacher's Organizational Citizenship Behavior and Organizational Identification in Public and Private Preschool. Social and Behavioral Sciences, 174, 1176-1182.

Dizari, A., \& Garoosi, R. (2015). Relationship between Teamwork and Organizational Agility from the Perspective of Employees of Social Security Organization Branch in Tehran. Journal of educational and management studies, 5(1), 288-232.

Erkutlu, H., \& Chafra, J (2016). Impact of Behavioral Integrity on Organizational Identification: The Moderating Roles of Power Distance and Organizational Politics. Management Research Review, 39(6), 672-691. https://doi.org/10.1108/MRR-01-2015-0011

Farid, H., Izadi, Z., Ismail, I. A., \& Alipour, F. (2015). Relationship between Quality of Work Life and Organizational Commitment among Lecturers in a Malaysian Public Research University. The Social Science Journal, 52(1), 54-61. https://doi.org/10.1016/j.soscij.2014.09.003

Farjad, H. R., \& Varnous, S. (2013), Study of Relationship of Quality of Work Life (QWL) and Organizational Commitment. Interdisciplinary Journal of Contemporary Research in Business, 4(9), 449-456.

Gayathiri, R., \& Ramakrishnan, L. (2013). Quality of Work Life - Linkage with Job Satisfaction and Performance. International Journal of Business and Management Invention, 2(1), 1-8.

Gok, S., Karatuna, I., \& Karaca, P. (2015). The Role of Percevid Supervisor Support and organizational Identification in Job Satisfaction. Social and Behavioral Sciences, 177, 38-42.

Gupta, M., \& Sharma, P. (2011). Factor Credentials Boosting Quality of Work Life of BSNLEmployees in Jammu Region. Asia Pacific Journal of Research in Business Management, 2(1), 79-89.

Hajevar, S., \& Kharazian, M. (2016). Analyzing Effect of organizational Agility and Intellectual Capital on productivity of Human Resources Through Spiritual Leadership. International Business Management, 10(10), 1893-1900.

He, H., Wang, W., Zhu, W., \& Harris, L. (2015). Service Workers' Job Performance: The Roles of Personality Traits, Organizational Identification, and Customer Orientation. European Journal of Marketing, 49(11/12), 1751-1776. https://doi.org/10.1108/EJM-03-2014-0132

Hill, C., \& Jones, G. (2009). Strategic Management, an Integrated Approach, 13th ed., Houghton Mifflin Company, Boston. 
Hitt, M. A., Hoskisson, E., Robert, I., \& Duane, R. (2007). Management of Strategy: Concepts and Cases, South-Western, 1st Ed., New York.

Jeon, K. S. (2011). The Relationship Of Perception Of Organization Performance And Spiritual Leadership, Workplace Spirituality, And Learning Organization Culture In The Korean Context, PhD dissertation, The Graduate School, The Pennsylvania State University,USA.

Karanika-Murray, M., Duncan, N., Pontes, H., \& Griffiths, M. (2015). Organizational Identification, Work Engagement, and Job Satisfaction. Journal of Managerial Psychology, 30(8), 1019-1033. https://doi.org/10.1108/JMP-11-2013-0359

Khoshlahn, M., \& Ardabili, F. (2016). The Role of Organizational Agility and Transformational Leadership in Service Recovery Prediction. Social and Behavioral Sciences, 230, 142-149. https://doi.org/10.1016/j.sbspro.2016.09.018

Kim, T., Karatepe, O., Lee, G., \& Xijing, C. (2017). Does Hotel Employees' Quality of Work Life Mediate the Effect of Psychological Capital on Job Outcomes? International Journal of Contemporary Hospitality Management, 29(6), 1638-1657. https://doi.org/10.1108/IJCHM-04-2016-0224

Koonmee, K., Singhapakdi, A., Virakul, B., \& Lee, D. J. (2010). Ethics Institutionalization, Quality of Work Life, and Employee Job-related outcomes: A Survey of Human Resource Managers in Thailand. Journal of Business Research, 63(1), 20-26. https://doi.org/10.1016/j.jbusres.2009.01.006

L'Hermitte, C., Tatham, P., Bowles, M., \& Brooks, B. (2016). Developing Organisational Capabilities to Support Agility in Humanitarian Logistics. Journal of Humanitarian Logistics and Supply Chain Management, 6(1), 72-99. https://doi.org/10.1108/JHLSCM-02-2015-0006

Liu, W., Zhang, P., Liao, J., Hao, P., \& Mao, J. (2016). Abusive Supervision and Employee Creativity: The Mediating Role of Psychological Safety and Organizational Identification. Management Decision, 54(1), 130-147. https://doi.org/10.1108/MD-09-2013-0443

Liu, Y., Loi, R., \& Lam, L., (2011). Linking Organizational Identification and Employee Performance in Teams: the Moderating Role of Team-member Exchange, 22(15), 318-320.

Markos, S., \& Sridevi, M. (2010). Employee Engagement: The Key to Improving Performance, International Journal of Business and Management, 5(12).

Mashkani, A., \& Khodadadi, M., (2016). The Mediating Role of Organizational Agility in the Relationship Between Organizational Learning and Organizational Performance. International Business Management, 10(16), 3530-3535.

Masoomzadeh, D., Feizi, M., \& Alipour, H. (2013). Surveying The Relationship Between Quality of Work Life Components and Counterproductive Behavior in Ardabil Province of Mellat Bank Employees, Arabian Journal of Business and Management Review (Nigerian Chapter), 1(3), 22-28. https://doi.org/10.12816/0003622

McCarthy, I. P., Lawrence, T. B., Wixted, B., \& Gordon, B. R. (2010). A Multidimensional Conceptualization of Environmental Velocity. Academy of Management Review, 35(4), 604-626. https://doi.org/10.5465/AMR.2010.53503029

Milton, L., \& Westphal, J. (2005). Identity Confirmation Networks and Co-operation in Work Group. Academy of Management Journal, 38(2), 191-212. https://doi.org/10.5465/AMJ.2005.16928393

Mirkamali, S. M., \& Thani, F. N. (2011). A Study on the Quality of Work Life among faculty members of University of Tehran and Sharif University of Technology. Procedia - Social and Behavioral Sciences, 29, 179-187. https://doi.org/10.1016/j.sbspro.2011.11.223

Mustafa, Z., Hamada, M., \& Yozgat, U. (2017). Does Organization Agility Affect Organizational Learning Capability? Evidence from Commercial banking. Management Science Letter, 7, 407-422.

Nafei, W. (2016). The Effect of Organizational Agility on Quality of Work Life: A Study on Commercial Banks in Egypt. International Journal of Business and Management, 11(6), 271. https://doi.org/10.5539/ijbm.v11n6p271

Najrani, M. (2016). The Endless Opportunity of Organizational Agility. Strategic Direction, 32(3), 37-38. https://doi.org/10.1108/SD-02-2015-0026

Narehan, H., Hairunnisa, M., Norfadzillah, R. A., \& Freziamella, L. (2014), The Effect of Quality of Work Life 
Programs on Quality of Life Among Employees at Multinational companies in Malaysia. Procedia - Social and Behavioral Sciences, 112, 24-34. https://doi.org/10.1016/j.sbspro.2014.01.1136

Nayak, T., \& Sahoo, C. (2015). Quality of Work Life and Organizational Performance: The Mediating Role of Employee Commitment. Journal of Health Management, 17(3), 263-273. https://doi.org/10.1177/0972063415589236

Nekouei, M. H., Othman, M. B., Masud, Jariah B., \& Ahmad, A. B. (2014). Quality of Work Life and Job Satisfaction among Employee in Government Organizations. Journal of Basic and Applied Scientific Research, 4(1), 217-229.

Overby, E., Bharadwaj, A., \& Sambamurthy, V. (2006). Enterprise Agility and the Enabling Role of Information Technology. European Journal of Information Systems, 15(2), 120-131. https://doi.org/10.1057/palgrave.ejis.3000600

Panda, S., \& Rath, S. (2016). Investigating the Structural Linkage between IT Capability and Organizational Agility: A Study on Indian Financial Enterprises. Journal of Enterprise Information Management, 29(5), 751-773. https://doi.org/10.1108/JEIM-04-2015-0033

Panda, S., \& Rath, S. (2017). The Effect of Human IT Capability on Organizational Agility: An Empirical Analysis. Management Research Review, 40(7), 800-820. https://doi.org/10.1108/MRR-07-2016-0172

Park, Y. (2011). The Dynamics of Opportunity and Threat Management in Turbulent Environments: The Role Information Technologies, Doctor Dissertation.

Parvar, M. R. F., Allameh, S. M., \& Ansari, R. (2013). Effect of Quality of Work Life on Organizational Commitment by SEM. International Journal of Academic Research in Business and Social Sciences, 3(10), 135-144. https://doi.org/10.6007/IJARBSS/v3-i10/285

Pavlou, P., \& El Sawy, O. (2010). The "Third Hand": IT-Enabled Competitive Advantage in Turbulence Through Improvisational Capabilities. Information Systems Research, 21(3), 443-471. https://doi.org/10.1287/isre.1100.0280

Pizam, A. (2010). International Encyclopedia of Hospitality Management, (2nd ed.. Burlington, USA: Elsevier Ltd, p 551.

Reddy, L., \& Reddy, M. (2010), Quality of Work Life of Employees: Emerging Dimensions. Asian Journal of Management Research, 827-839.

Saha, N., Gregar, A., \& Saha, P. (2017). Organizational Agility and HRM Strategy: Do the Really Enhance Firm's Competitiveness? International Journal of Organizational Leadership, 6, 323-334.

Saks, A. (2006). Antecedents and Consequences of Employee Engagement. Journal of Managerial Psychology, 21(7), 600-619. https://doi.org/10.1108/02683940610690169

Shani, S. (2013). A Study on Quality of Work Life Among the Employees at Metro Engineering Private Limited. International Journal of Management, 4(1), 1-5.

Sharma, N., \& Verma, D. S. (2013). Importance of Quality of Work Life in Small Scale Industries For Employees. International Journal of Latest Research in Science and Technology, 2(2), 153-156.

Sherehiy, B. (2008). Relatioships Between Agility Strategy, Work Organization and Workforce Agility, Doctor Dissertation, University of Louisville.

Simon, H. (2000). Public Administration in Today's World of Organizations and Markets. Political Science and Politics, 33(4), 749-756.

Sverke, M., Hellgren, J., \& Nas wall, K. (2006). Job Insecurity: A Literature Review, The National Institute for Working Life and The Swedish Trade Unions in co-operation, Report 1.

Swamy, D., Nanjundeswaras wamy, T., \& Rashmi, S. (2015). Quality of Work Life: Scale Development and Validation. International Journal of Caring Sciences, 8(2), 281-300.

Terzi, A., Dulker, A., Altn, F., Celik, F., Dalkran, M., Yulcu, N., ... Deniz, U. (2017). An Analysis of Organizational Justice and Organizational Identification Relation Based on Teacher's Perceptions. Universal Journal of Educational Research, 5(3), 488-495. https://doi.org/10.13189/ujer.2017.050320

Timossi, L. D., Pedroso, B., Francisco, A. C., \& Pilatti, L. A. (2008). Evaluation of Quality of Work Life: An Adaptation from the Walton's QWL Model. Proceeding of the XIV International Conference on Industrial Engineering and Operations Management, Rio de Janeiro, Brazil. 
Tsourveloudis, N., \& Valavanis, K., (2002). On the Measurement of Enterprise Agility. Journal of Intelligent \& Robotic Systems, 33(3), 329-342. https://doi.org/10.1023/A:1015096909316

Vondey, M. (2010) The Relationship among Servant Leadership, Organizational citizenship Behavior, PersonOrganization Fit and Organizational Identification. International Journal of Leadership studies, 16(1), 7-23.

Warr, P., \& Inceoglu, I. (2012). Job Engagement, Job Satisfaction, and Contrasting Associations With Person-Job Fit. Journal of Occupational Health Psychology, 17(2), 129-138. https://doi.org/10.1037/a0026859

Zain, M., Rose, R., Abdullah, I., \& Masrom, M. (2005). The Relationship between Information Technology Acceptance and Organizational Agility in Malaysia. Information \& Management, 42, 829-839. https://doi.org/10.1016/j.im.2004.09.001

\section{Copyrights}

Copyright for this article is retained by the author(s), with first publication rights granted to the journal.

This is an open-access article distributed under the terms and conditions of the Creative Commons Attribution license (http://creativecommons.org/licenses/by/4.0/). 